\title{
PEMIKIRAN POLITIK ISLAM AHMAD HASSAN PERSPEKTIF POLITIK ISLAM INDONESIA
}

\author{
Muh. Rifali \\ Madrasah Aliyah al-Fatah Temboro Karas Magetan | malaikat.kiamat@gmail.com
}

\begin{abstract}
This article analyzesthe Islamic political thought of Ahmad Hasan within the political perspective of Indonesia Islam. According to Hassan's point of view, Islam is a complete religion which regulates all aspects of human life ranging from spiritual to politics. For the sake of establishing an Islamic state in accordance with the will of God, Muslims should carry out all of the Islamic teachings in every situation of life. Laws and regulations in accordance with al-Qur'an should be implemented. Islam, for him, is another option of a national ideology that considers no place for religion. He wants Islam to regulate all aspects of human life, based on the belief that Islam is the absolute truth. Islam is seen as something of the highest and widest beyond national boundaries and lines. Thus, Hassan is considered a fundamentalist thinker. In the struggle for the enforcement of Islamic Shariah, he wants to transform the Islamic community to its original root. He firmly believed that Muslims in Indonesia are infected by spiritual disease which ought to be cured with a radical revolutionary way. Thus, he suggested, that at personal level, a Muslim should apply the Islamic law in every place and every time.
\end{abstract}

Keywords: Ahmad Hassan's thought, concept of political Islam, Islamic political development in Indonesia

Abstrak: Artikel ini mempresentasikan tentang pemikiran politik Islam menurut Ahmad Hasan dalam perspektif politik Islam Indonesia. Dalam pandangan Ahmad Hassan, Islam adalah agama yang lengkap yang mengatur sendi-sendi kehidupan manusia mulai dari karohanian sampai masalah politik kenegaraan. Demi mewujudkan suatu negara Islam yang sesuai dengan yang dikehendaki Tuhan, maka kaum muslimin harus melaksanakan seluruh ajaran agama Islam di setiap sendi kehidupan. Undang-undang dan peraturan-peraturan yang sesuai dengan al-Qur'an harus dilaksanakan. Pemerintahan Islam baginya adalah pilihan lain dari faham kebangsaan yang dianggapnya sebagai 
tidak memberikan tempat bagi agama. la menginginkan Islam memasuki seluruh aspek kehidupan manusia, sesuai dengan keyakinan bahwa kebenaran ajaran Islam adalah mutlak. Islam dipandang sebagai sesuatu yang tertinggi dan terluas menerjang batas-batas kebangsaan dan ketanah-airan. Ahmad Hassan adalah seorang pemikir yang fundamentalis, dalam memperjuangkan tegaknya syari'at Islam, Ahmad Hassan ingin mengubah masyarakat Islam sampai ke akar-akarnya, dan ingin menghancurkan penyakit umat Islam dengan cara yang radikal secara revolusioner, secara jelas, tanpa samar-samar dan penuh kepastian. Suka atau tidak suka, menurut Ahmad Hassan, seorang muslim harus menggunakan hukum Islam di setiap tempat dan setiap hal.

Kata Kunci: Pemikiran Ahmad Hassan, konsep politik Islam, perkembangan politik Islam Indonesia

\section{Pendahuluan}

Dalam diskursus keagamaan kontemporer, dijelaskan bahwa "agama" ternyata mempunyai banyak wajah (multifaces) dan bukan lagi seperti pemahaman orang-orang terdahulu, yakni sematamata hanya terkait dengan persoalan ketuhanan, kepercayaan, keimanan, kredo, pedoman hidup, dan seterusnya. Selain ciri dan sifat konvensionalnya yang memang mengasumsikan bahwa persoalan keagamaan hanyalah semata-mata persoalan ketuhanan, agama juga terkait erat dengan persoalan-persoalan historis kultural yang merupakan keniscayaan manusia. ${ }^{1}$

Campur aduk masalah keagamaan dengan kepentingankepentingan yang lain, merupakan suatu persoalan keagamaan kontemporer yang paling rumit untuk dipecahkan. Apalagi terkait masalah agama dengan politik kenegaraan. Karena memang hal itu mempunyai multi tafsir, dan analisis serta sudut pandang yang berbeda dari para pemikir.

Wacana tentang hubungan antara Islam dan politik, atau Islam dan negara senantiasa menarik untuk dikaji. Karena wacana

' Moh Shoffan, Jalan Ketiga Pemikiran Islam: Mencari Solusi Perdebatan Tradisionalisme dan Liberalisme, (Jogjakarta: Ircisod, 2006), 5. 
tersebut juga melibatkan berbagai kalangan, baik itu dari kiai, politisi, akademisi, partai maupun negara, dan juga melintasi rentang waktu yang panjang dalam sejarah politik di negeri ini. Wacana tersebut telah melahirkan berbagai bentuk konflik dan kompromi yang mencerminkan kekuatan sekaligus kelemahan kelompok Islam itu sendiri. Dengan kekuatan dan kelemahan itu, Islam diharapkan bisa lebih kongkrit berperan dalam kehidupan bernegara.

Ada beberapa hal yang menarik perhatian para pemikir, aktifis dan ahli hukum muslim Indonesia selama kurang lebih enam puluh tahun, sejak kemerdekaan Indonesia. Mereka ingin membaharui muslim Indonesia dengan wajah yang baru dan dengan pemikiran yang baru pula. Seperti kaum muslimin di belahan dunia lainnya, kaum muslim Indonesia merespon beberapa persepsi tersebut secara berbeda. ${ }^{2}$

Dari respon yang yang ada, kelompok muslim dapat dikategorisasikan menjadi beberapa kelompok. Salah satu kelompok utama yang sering disebut dengan "santri", yakni kelompok muslim yang mengidentifikasi diri dengan kuat pada keyakinan, ritual, dan fikih tradisional Islam Timur Tengah dan berupaya menyesuaikan budaya lokal, pemikiran intelektual, dan istitusi-institusi politik dengan sistem keagamaan tersebut. ${ }^{3}$ Istilah santri ini menjadi istilah yang multi makna tergantung pada konteks apa kata ini digunakan. Dalam bahasa antropologi seperti dikenalkan oleh Clifford Geertz, santri adalah varian yang dilawankatakan dengan kata abangan, yang tidak memiliki gairah keIslaman lebih dari sekedar identitas kependudukan. Sementara dalam terma keagamaan di Indonesia, santri bermakna orangorang yang pernah belajar di pesantren. ${ }^{4}$

Kelompok kedua yang sering disebut "muslim puritan" masih terikat dengan adat-istiadat dan nilai-nilai pribumi Asia Tenggara,

\footnotetext{
${ }^{2}$ Howard M. Federspiel, Labirin Idiologi Muslim, (Jakarta: PT Serambi Ilmu Semesta, 2004), 7.

${ }^{3}$ lbid., 7.

${ }^{4}$ lbid.
} 
yang kadang-kadang memperbaharui keyakinan dan ritual Islam agar terhubung dengan beberapa ciri penting dari nilai-nilai pribumi dan menyukai teknologi serta mendukung solusi-solusi politik yang tampak sesuai dengan sistem nilai ini. ${ }^{5}$

Kelompok ketiga yang sering disebut dengan "nasionalis" merespon pemikiran sekuler barat tentang negara bangsa, tentang pentingnya nilai-nilai kewargaan yang muncul secara nasional, dan tentang pengunaan teknologi untuk menciptakan ekonomi nasional yang makmur. ${ }^{6}$

Perbedaan ketiga kelompok tersebut di atas terletak pada aspek interpretasi ideologis yang melatarbelakangi aplikasi pikiran-pikiran kebangsaan mereka. Tujuannya sama mulia, yaitu merealisasikan kedamaian, kemakmuran dan kesejahteraan. Tetapi bagaimana menggapainya adalah hal yang berbeda. Inilah yang melahirkan perbedaan simbol dan wacana di antara mereka.

Interaksi dari ketiga kelompok ini merupakan faktor penting dalam perkembangan kehidupan sosial dan politik di Indonesia pada abad yang lalu. Ada problem-problem nyata dalam masalah ini, tapi beberapa kategori semacam ini penting untuk mengindentifikasi kelompok-kelompok dalam kehidupan masyarakat Indonesia saat ini.

Organisasi-organisasi Islam utama, yang muncul di Indonesia pada abad ke-20, antara lain Syarekat Islam, Muhammadiyyah, Nahdlatul Ulama' dan Masyumi. Semuanya mewakili kelompok yang menekankan keyakinan-keyakinan dan praktek-praktek Islam Timur Tengah Tradisional. ${ }^{7}$ Semua mementingkan keunggulan hukum Islam, walaupun konsep-konsep mereka tentang apa sebenarnya hukum Islam itu kabur antara satu dengan yang lainnya.

Alasan-alasan yang menyebabkan tidak terjadinya kesepakatan dan kekaburan itu terletak pada perbedaan-

${ }^{5}$ lbid., 8.

${ }^{6}$ Ibid.

${ }^{7}$ Ibid. 
perbedaan tentang apa yang sebenarnya membentuk sumbersumber agama Islam, walaupun ada perbedaan interpretasi tertentu mengenai sumber-sumber ini. Kaum tradisionalis (kaum tua), yang diwakili oleh Nahdlatul Ulama', meyakini bahwa kebenaran agama termuat di dalam tulisan-tulisan ulama' salaf, khususnya kitab yang ditulis oleh fuqaha' dan para teolog.

Kaum modernis (kaum muda), yang diwakili oleh Muhammadiyyah, berpendapat bahwa penelitian dan interpretasi baru (ijtihad) terhadap dasar-dasar agama harus dilakukan, bukan bertumpu pada tradisi para penafsir masa silam. Pendekatan ketiga mungkin lebih tepat sebagai sesuatu variasi dari pendekatan kaum modernis, yang diwakili oleh Persatuan Islam, yaitu memberikan penekanan khusus pada makna penting alQur'an dan Sunnah sebagai sumber penelitian keagamaan. ${ }^{8}$

Dari berbagai pandangan tentang kebenaran agama yang termuat dalam al-Qur'an dan Sunnah serta hubunganya dengan teori suatu negara Islam memang menjadi suatu masalah tersendiri. Di dunia pesantren, sulit diperoleh suatu karya yang berarti tentang masalah ini. Banyak kalangan yang berbicara tentang sebuah negara dengan agama, namun sayangnya belum ada yang mampu mengartikulasikan hakekat dan corak suatu negara yang ingin mereka ciptakan. ${ }^{9}$ Federspiel mengolongkan kelompok masyarakat yang memandang hakekat dan corak suatu negara menjadi tiga.

Pertama, adalah golongan sekuler, yakni golongan yang memisahkan antara agama dan negara, mereka memandang bahwa antara agama dan negara tidak ada kaitannya, keduanya berjalan sendiri-sendiri. Agama dipandang hanya mengatur urusan individu dengan Tuhannya dan negara terlepas dari aturan-aturan agama itu. Negara mempunyai cara sendiri untuk

\footnotetext{
${ }^{8}$ Howard M. Federspiel, Persatuan Islam, (Yogyakarta: Gajah Mada Universiti Press, 1996), 19.

9 Ahmad Syafí Ma'arif, Islam dan Masalah Kenegaraan, Studi Tentang Pencarian dalam Konstituante, (Jakarta: LP3ES, 1996), Cet III, 125.
} 
mengatur pemerintahannya, dan tanpa agamapun suatu negara bisa berdiri sendiri.

Kedua, ada yang menganggap bahwa dalam ajaran Islam sendiri tidak dijelaskan secara rinci tentang bagaimana cara mengatur negara itu sendiri, karena konsep kenegaraan dalam Islam tidak pernah baku tentang teori ini (baca: sistem politik), mulai dari zaman Nabi S.A.W, para sahabat, tabi'in, sampai pada para intelektual dan politisi Islam sekarang ini. ${ }^{10}$ Dengan situasi yang seperti itulah, tidak jarang dan bahkan sering sekali akan menimbulkan konflik dan peperangan yang ahirnya bermuara pada perpecahan dan hilangnya persatuan Islam dan rasa kebersamaan diantara umat Islam itu sendiri. ${ }^{11}$ Dari sisi lain ada anggapan pemikiran yang menghendaki bahwa Islam tidak harus secara simbolik masuk dalam kehidupan negara, tetapi yang terpenting adalah bagaimana nilai-nilai dan prinsip Islam itu masuk dalam sejarah kehidupan politik dan bernegara, baik melalui pendekatan spritual atau kultural dengan akhlakul karimah seperti yang dilakukan Nabi S.A.W yang bisa menciptakan hubungan yang harmonis dan mesra antar sesama rakyat.

Ketiga, dianggap sebagai pemikiran simbiosis mutualisme. yang menganggap bahwa, Islam adalah agama yang sempurna, Islam dan politik terkait secara organik, atau tidak dapat dipisahkan ${ }^{12}$. Islam memuat cara hidup yang lengkap, yakni totalitas lengkap yang menawarkan pemecahan terhadap semua masalah kehidupan. Mengatur sendi-sendi kehidupan sampai masalah politik. Bahwa Islam adalah agama sekaligus negara. Antara Islam dan negara merupakan satu kesatuan yang saling menyatu, saling berinteraksi di mana negara berdasarkan syari'at Islam dengan ulama' sebagai penasehat resmi sebagai eksekutif atau bahkan

\footnotetext{
${ }^{10}$ AH. Zakki Fuad, Negara Islam atau Negara Nasional, (Kediri: Jenggala Pustaka Utama, 2007), 5.

"Ibid., 6.

${ }^{12}$ Abdul Aziz, Politik Islam Politik, (Yogyakarta: Tiara Wacana, 2006), I I .
} 
pemegang kekuasaan tertinggi. Islam menjadi keniscayaan untuk dipakai sebagai dasar untuk mengatur kehidupan suatu negara

Dan salah satu pemikir politik Islam di Indonesia yang senada dengan pemikiran politik Islam tradisional atau pemikiran fundamental dan yang agak lebih extrim dalam pemikiran politik itu adalah Ahmad Hassan. Ahmad Hassan adalah figur sebagai seorang ulama' dan juga tokoh sentral dalam Persatuan Islam, yaitu sebuah partai Islam di awal menuju kemerdekaan Indonesia.

Dari beberapa kajian tentang Persatuan Islam inilah, penulis mengungkapkan pemikiran-pemikiran Ahmad Hassan, karena ia salah satu pemikir utama dalam Persatuan Islam, yaitu sebuah partai yang secara formal berdiri pada 11 September 1923 di Bandung ${ }^{13}$. Sebuah partai yang salah satu tujuan pendirianya adalah untuk memperluas diskusi-diskusi tentang keagamaan.

Hassan bin Ahmad sering ditulis dengan Ahmad Hassan atau A. Hassan. Bahkan ada yang menyebut dengan Hassan Bandung karena perjuangannya dimulai dari Bandung. Ahmad Hassan adalah pahlawan sekaligus tokoh pemikir Islam Indonesia yang menghendaki keharusan adanya pemerintahan Islam. Ahmad Hassan menginginkan Islam memasuki seluruh aspek kehidupan manusia, sesuai dengan keyakinannya, bahwa kebenaran ajaran Islam adalah mutlak.

Bukti nyata dari apresiasi ini adalah terus berkarya dan berkreativitas dalam mengisi pembangunaan bangsa, meneruskan perjuangannya yang belum tercapai serta tetap memiliki rasa nasionalisme yang tinggi disertai dengan nilai-nilai religiusitas yang cukup militan. Apabila kedua unsur tersebut berintegrasi pada seorang warga bangsa, maka hampir bisa dipastikan negara tesebut memiliki harkat dan martabat yang cukup tinggi di mata dunia internasional. ${ }^{14}$

Pergulatan politik pada masa kemerdekaan Indonesia adalah siasat politik yang masih murni sebagai gerakan nasional yang

\footnotetext{
${ }^{13}$ Howard M. Federspiel, Persatuan Islam, 14.

${ }^{14}$ Deddy Rahman, Ulama'Besar. Adiy an-Nawawi. www.com diakses Maret 2009
} 
melakukan resistensi (perlawanan) terhadap penjajah dalam hal ini adalah Belanda dan Jepang. Gerakan politik pada masa ini ditandai dengan sikap yang masih menjunjung tinggi kebersamaan dan meminimalisasi aspek-aspek yang justru akan menimbulkan perpecahan dan pada ujungnya menyebabkan sulitnya mewujudkan kemerdekan Indonesia.

Dalam dinamikanya di Indonesia, pemikiran tentang Islam politik juga menampakkan wajah yang kompleks. Hal itu bisa dilihat pada masa lalu, yakni abad ke-13 dan abad ke-14, ketika Islam dikenalkan dan disebarluaskan di Indonesia. Bangkitnya gerakan nasionalisme pada dekade awal abad ke-20 menandai permulaan diskursus Islam politik secara lebih jelas. Pada masa itu, gerakan masyarakat pribumi mulai bermunculan dengan visi politik yang jelas, yakni menentang kolonialisme Belanda dan menuntut kemerdekaan bagi bangsa Indonesia. Tidak diragukan lagi, dalam gerakan nasionalistik itu Islam memainkan peran penting, bahwa Islam bukan saja mata rantai yang mengikat nasionalisme Indonesia, melainkan juga menjadi simbol kesamaan nasib dalam menentang penjajahan Belanda. ${ }^{15}$

Tapi Menurut Ahmad Hassan yang juga tokoh Persatuan Islam (Persis) ini, ia mengatakan bahwa nasionalisme sama dengan 'ashabiyyah. Berpegang teguh pada 'ashabiyyah dan berjuang dengan 'ashabiyyah maupun menggunakan dasar atau landasan 'ashabiyyah adalah tidak termasuk golongan Nabi Muhammad saw. Maka, atas dasar ini bisa disimpulkan bahwa nasionalime atau paham kebangsaan bertentangan dengan ajaran Islam. ${ }^{16}$

Hal itulah yang dikatakan oleh Ahmad Hassan dengan pergerakan faham kebangsaan saat itu, sehingga ia menilai "bahwa masuk dan membantu pergerakan-pergerakan yang berdasar kebangsaan itu dosa, karena sekurang-kurangnya pergerakan kebangsaan itu menuju kepada membuang undang-undang Allah

${ }^{15}$ Abdul Aziz, Politik Islam Politik, 23.

${ }^{16}$ Syafiq A. Mughni, Hassan Bandung: Pemikir Islam Radikal, (Surabaya: PT Bina Ilmu, 1994), 34.

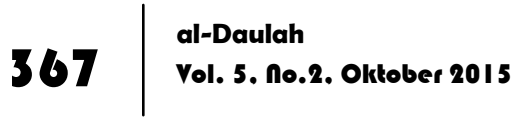


dan Rasul-Nya dan menggantikan dengan hukum-hukum buatan manusia"17.

Kerangka berfikir Ahmad Hassan banyak dipengaruhi oleh orang tuanya yang berfaham Wahabi ${ }^{18}$. Konsep pemikiran Ahmad Hassan berangkat dari pengakuannya bahwa hanya al-Qur'an dan Sunnah sajalah yang menjadi pokok sumber hukum Islam. Selanjutnya ia menyatakan bahwa umat Islam harus melaksanakan hukum-hukum Allah dan untuk itu harus ada pemerintahan Islam. Hal ini didasarkan pada ayat-ayat al-Qur'an yang mengharuskan adanya hukum-hukum Allah tersebut, jika tidak ada maka kita akan berbuat kezaliman. ${ }^{19}$

Dari berbagai gambaran latar belakang tersebut, penulis tertarik melakukan kajian terhadap pemikiran Ahmad Hassan. Meskipun ada yang memandang bahwa tokoh ini kecil, tidak begitu populer, tapi tidak bagi penulis. Ada sisi-sisi menarik yang penulis tangkap dari hasil pemikiran beliau, yaitu dibidang politik atau kebangsaan. Tentang pandangan beliau terhadap politik Islam itu sendiri serta implikasi pemikiran beliau terhadap perkembangan politik Islam di Indonesia.

\section{Riwayat Hidup Ahmad Hassan}

Ahmad Hassan dilahirkan di Singapura pada tahun 1887. Dengan nama kecilnya Hassan bin Ahmad, beliau terlahir dari pasangan seorang Bapak bernama Ahmad dan Ibu yang bernama Muznah, yang mempunyai asal-usul dari Mesir. Mereka menikah di Surabaya, yaitu ketika Ahmad sedang melakukan perjalanan perdagangan di kota Padang. Setelah menikah, Ahmad memboyong Muznah ke Singapura, meskipun Muznah lahir di

\footnotetext{
${ }^{17}$ A. Hassan, Islam dan Kebangsaan, (Bangil: Persatuan, 1972), Cet III, 25.

${ }^{18}$ Wahabi adalah suatu istilah yang dinisbatkan kepada Muhammad bin Abdul Wahab (I703|79|), seorang ulama' yang mengadakan gerakan pemurnian ajaran Islam, terutama di bidang akidah.

${ }^{19} \mathrm{AH}$. Zakki Fuad, Negara Islam atau Negara Nasional, 148.
} 
Surabaya, Muznah berasal dari Pelakat, Madras. ${ }^{20}$ Sedangkan Ahmad sendiri berasal dari India dan bergelar Pandit.

Ayah Ahmad Hassan adalah pengarang dan pemimpin surat kabar "Nurul Islam" yang terbit di Singapura. ${ }^{21}$ Ayah Ahmad Hassan adalah orang yang ahli dalam bahasa dan agama, dan ia tak jarang terlibat dalam perdebatan mengenai dua persoalan itu (bahasa dan agama). Di dalam surat kabarnya Ahmad mengasuh rubrik Tanya-Jawab.

Semasa hidupnya, Ahmad Hassan hanya mempunyai seorang istri yang bernama Maryam, yang dinikahinya di Singapura pada tahun 1911. Maryam adalah seorang peranakan Tamil-Melayu, dari keluarga yang taat beragama. Dari pernikahannya itu, pasangan Ahmad Hassan-Maryam dikaruniai 7 anak. Satu di antaranya adalah Abdul Qadir Hassan, yang juga penerus ayahnya. Pada tahun 1940, Ahmad Hassan pindah ke Bangil, Pasuruan, Jawa Timur, untuk mendirikan dan mengasuh pondok pesantren Persis. Dan pada tanggal 10 November 1958, Ahmad Hassan menghadap pada-Nya. Allah..$^{22}$

Sebagai anak laki-laki, ayahnya juga menginginkan Ahmad Hassan apabila besar nanti menjadi seorang penulis sepertinya juga. Untuk maksud itu, dia berusaha memberi pendidikan secukupnya kepada Ahmad Hassan. Dan suatu keistimewaan yang dianugerahkan Allah kepada Ahmad Hassan, dalam usia 7 tahun, dia sudah mulai mempelajari al-Qur'an dan pengetahuan asas dalam bidang agama. Berkat ketekunan dan kecerdasannya, kedua pelajaran ini dapat diselesaikannya dalam tempuh dua tahun. setelah itu Ahmad Hassan masuk sekolah Melayu selama 4 tahun dan mempelajari bahasa Arab, bahasa Melayu, bahasa Tamil dan bahasa Inggris.

Secara formal, Ahmad Hassan tidak pernah benar-benar menamatkan pelajarannya di sekolah dasar yang ditempuhnya di

\footnotetext{
${ }^{20}$ Harry Muhammad, dkk, Tokoh-Tokoh Islam yang Berpengaruh Abad-20, 14.

${ }^{2 !} \mathrm{AH}$. Zakki Fuad, Negara Islam atau Negara Nasional, 146.

${ }^{22}$ Harry Muhammad dkk, Tokoh-Tokoh Islam yang Berpengaruh Abad-20, 19.
} 
Singapura itu, karena pada usia 12 tahun Ahmad Hassan sudah ikut berdagang, menjaga toko iparnya yang benama Sulaiman. Sambil berdagang, Ahmad Hassan memperdalam ilmu agamanya pada Haji Ahmad di Bukittiung dan Muhammad Thaib di Minto Road. Haji Ahmad bukanlah seorang alim besar, tetapi buat ukuran Bukittiung ketika itu, ia adalah seorang guru yang disegani dan berakhlak tinggi. Pelajaran yang diterima Ahmad Hassan sama saja dengan apa yang diterima anak-anak muda waktu itu, yakni bagaimana cara sembahyang, wudlu', puasa dan lain-lain.

Ahmad Hassan mempelajari ilmu nahwu dan sharaf pada Muhammad Thaib. Ahmad Hassan sebagai seorang yang keras kemauannya dalam belajar ilmu tata bahasa Arab, nahwu dan sharaf, tidak merasa keberatan menerima segala persyaratan yang diperuntukan baginya. Persyaratan itu antara lain: pertama, Ahmad Hassan harus datang pagi-pagi sebelum sembahyang shubuh. Kedua, Ahmad Hassan tidak boleh naik kendaraan ke tempat gurunya itu. Setelah kira-kira empat bulan belajar nahwu dan sharaf, ia merasa bahwa pelajarannya tidak mendapat kemajuan. Namun apa yang disuruh gurunya dikerjakan dan dihafal juga, tanpa dimengerti, ahirnya semangat belajanya menurun. Dalam keadaan demikian, untunglah gurunya tersebut pergi haji dan beliau beralih belajar pada Sid Abdullahal Masnawi. Beliau semata-mata belajar bahasa arab dan menempuhnya selama waktu tiga tahun. ${ }^{23}$

Di samping itu, beliau belajar agama pada Abdul Lathif, seorang yang terkenal di Malaka dan Singapura, ia belajar pula pada Syekh Hassan seorang yang berasal dari Malabar, dan Syekh Ibrahim, ulama' yang berasal dari India. Semua itu di tempuh kirakira tahun 1910, ketika ia berusia 23 tahun. Ahmad Hassan pada waktu itu belum memiliki pengetahuan luas tentang agama, misalnya fara'id, fiqh, mantiq, dan lain-lainya, tetapi dalam ilmu alat yang dimiliki itulah ia memperdalam pengetahuan agamanya.

${ }^{23}$ Syafiq A Mughni, Hassan Bandung, Pemikir Islam Radikal, 12.

\begin{tabular}{l|l}
370 & $\begin{array}{l}\text { al-Daulah } \\
\text { Vol. 5. no.2. Oktober } 2015\end{array}$
\end{tabular} 


\section{Definisi Politik Islam}

Istilah politik dalam kamus ilmiah Indonesia diartikan sebagai siasat, kebijakan yang menyangkut urusan kenegaraan ${ }^{24}$. Sedangkan politik dalam bahasa Arabnya disebut "Siyasah" atau dalam bahasa Inggrisnya "politic". Politik itu sendiri berarti cerdik atau bijaksana. Namun dalam pembicaraan yang sering kita pakai setiap hari, biasanya politik diartikan sebagai suatu cara untuk mensiasati lawan, baik siasat itu dengan cara yang positif atau dengan cara negatif yang berfungsi untuk mewujudkan suatu tujuan. Tetapi sebenarnya para ahli politik pun mengakui bahwa sangat sulit memberikan definisi tentang ilmu politik.

Pada dasarnya politik mempunyai ruang lingkup negara, membicarakan politik sama saja membicarakan negara atau tata pemerintahan, karena teori politik menyelidiki negara sebagai lembaga politik yang mempengaruhi hidup masyarakat, jadi negara dalam keadaan bergerak. Selain itu politik juga menyelidiki ide-ide, asas-asas, sejarah pembentukan negara, hakekat negara serta bentuk dan tujuan negara.

Asal mula kata politik itu sendiri berasal dari kata "polis" yang berarti "negara kota", dengan politik berarti ada hubungan khusus antara manusia yang hidup bersama dan dalam hubungan itu timbul aturan, kewenangan, dan akhirnya kekuasaan. Tapi politik bisa juga dikatakan sebagai kebijaksanaan, kekuatan, kekuasaan, pemerintahan, konflik dan pembagian atau kata-kata serumpun. ${ }^{25}$

Terminologi politik pada dasarnya pertama kali dikenalkan dari buku Plato yang bejudul poletea, yang kemudian dikenal dengan Republik. Istilah tersebut kemudian ditemukan pula dalam karya Aristoteles, murid Plato yang berjudul politea. Kedua karya tersebut dipandang sebagai pangkal pemikiran politik yang berkembang kemudian. Artinya pergulatan tentang politik,

${ }^{24}$ M. Dahlan dkk, Kamus Induk Istilah IImiah, 62I.

${ }^{25}$ Inu Kencana Syafi'i, IImu Politik, (Jakarta: PT Rieneka Cipta, 2000), I 8. 
utamanya berkaitan dengan historis, tidak bisa dilepaskan dari kedua karya monumental tentang politik di atas ${ }^{26}$.

Istilah politik dari Plato dan Aristoteles merupakan kata yang dipergunakan untuk konsep pengaturan masyarakat. Kedua filosof tersebut menekankan pembahasan tentang politik berkaitan dengan masalah, yaitu bagaimana pemerintahan dijalankan agar terwujud sebuah masyarakat politik atau negara yang paling baik. Agar upaya tersebut berhasil, maka politik memerlukan seperangkat alat atau unsur-unsurnya, seperti menjalankan pemerintahan, masyarakat sebagai pihak yang berkepentingan, kebijaksanaan dan hukum-hukum yang menjadi sarana pengaturan masyarakat, dan cita-cita yang hendak dicapai. ${ }^{27}$

Ada juga yang mengartikan politik ke dalam dua definisi. Pertama, pandangan yang mengkaitkan politik dengan negara, yakni dengan urusan pemerintahan pusat atau pemerintahan daerah. Kedua, pandangan yang mengkaitkannya dengan masalah kekuasaan, otoritas dan konflik. Maka perbedaan pengertian ini berkaitan dengan digunakanya pendekatan yang berbeda tentang politik, yaitu pendekatan tradisional dan pendekatan prilaku.

Dengan demikian, politik berkaitan dengan segala sesuatu yang berkenaan dengan pengelolaan negara beserta ruang lingkupnya. Pengkaitan pengelolaan negara bertujuan agar fungsifungsi kenegaraan berjalan dengan baik. Pengelolaan tersebut pada akhirnya tidak hanya berkaitan dengan sistem negara, tetapi juga berkaitan dengan prilaku politik dan institusi politik dalam negara. Jadi hakekat politik adalah prilaku manusia, baik berupa aktifitas ataupun sikap, yang bertujuan mempengaruhi dan mempertahankan tatanan sebuah masyarakat dengan mengunakan kekuasaan.

Sedangkan dalam Islam, istilah politik Islam berarti "siyasah shar'iyyah" yang diartikan sebagai ketentuan kebijaksanaan pengurusan masalah kenegaraan yang berdasarkan syari'at Islam.

${ }^{26}$ Listiyono Santoso, Teologi Politik Gus Dur, (Jogjakarta: Ar-Ruzzjogjakarta, 2004), 167.

${ }^{27}$ Ibid., 167. 
Menurut Abdul Wahab Khalaf, sebagaimana dikutip oleh Listono Santoso, bahwa siyasah shar'iyyah diartikan sebagai pengelolaan masalah-masalah umum bagi pemerintahan Islam yang menjamin terciptanya kemaslahatan dan terhindarnya kemudaratan dari masyarakat Islam, dan tidak bertentangan dengan ketentuan syari'at Islam dan prinsip-prinsip umumnya, meskipun tidak sejalan dengan pendapat para ulama' mujtahid. ${ }^{28}$ Definisi ini lebih dipertegas lagi oleh Abdurrahman Taj yang merumuskan siyasah shar'iyyah sebagai hukum-hukum yang mengatur kepentingan negara, mengorganisasi permasalahan umat sesuai dengan jiwa (semangat) syari'at dan dasar-dasarnya yang universal demi terciptanya tujuan-tujuan kemasyarakatan, walaupun pengaturan tersebut tidak ditegaskan oleh al-Qur'an dan al-Sunnah.

Dari beberapa pandangan tokoh Islam tentang pandangan siyasah shar'iyyah politik Islam di atas dapat dirumuskan tentang pengertian siyasah shar'iyyah, yaitu:

1. Bahwa siyasah shar'iyyah berhubungan dengan pengurusan dan pengaturan kehidupan manusia

2. Bahwa pengurusan dan pengaturan ini dilakukan oleh pemegang kekuasaan

3. Bahwa tujuan pengaturan tersebut adalah untuk menciptakan kemaslahatan dan menolak kemudaratan

4. Bahwa pengaturan tersebut tidak boleh bertentangan dengan ruh atau semangat syari'at Islam yang universal. ${ }^{29}$

Berdasarkan hakekat siyasah shar'iyyah dapat disimpulakan bahwa sumber-sumber pokok siyasah shar'iyyah adalah wahyu alQur'an dan Sunnah. Kedua sumber inilah yang menjadi acuan bagi pemegang pemerintahan untuk menciptakan peraturanperaturan untuk mengatur kehidupan bernegara, namun aturan itu juga bisa terbentuk dari manusia itu sendiri dari lingkungan

\footnotetext{
${ }^{2}$ Muhammad Iqbal, Fiqh Siyasah: Kontekstualisasi Doktrin Politik Islam, Jakarta: Gaya Media Pranata, 200I), 5.

${ }^{29}$ Ibid., 6.
} 
sekitar yang berupa pendapat para ahli, yurisprudensi, adat istiadat yang berlaku.

\section{Posisi Pemikiran Ahmad Hassan dalam Peta Perkembangan Politik Islam di Indonesia}

Salah satu masalah yang dihadapi oleh negeri yang mayoritas berpenduduk muslim pada awal pembentukannya adalah bagaimana mendudukkan agama dalam kehidupan bernegara. Dalam pandangan Delier Noer, Islam setidaknya meliputi dua aspek pokok yaitu agama dan masyarakat atau politik. Akan tetapi, untuk mengartikulasikan dua aspek pokok tersebut dalam realitasnya menjadi suatu problem tersendiri. ${ }^{30}$

Ketika Indonesia membangun hubungan antara agama dan politik terjadi kesulitan. Kesulitan ini pernah diungkapkan oleh Zifirdaus Adnan sebagaimana dikutip Bactiar Efendi, Ia menjelaskan bahwa hubungan ini begitu sulit sebab terdapat dua arus besar: pertama, kelompok yang menghendaki adanya kaitan formal antara Islam dan negara, baik dalam bentuk negara Islam, Islam sebagai negara, atau negara yang memberlakukan Islam. Kedua, kelompok yang menentang kaitan antara Islam dan negara dalam bentuk apapun. ${ }^{31}$ Hubungan yang tidak harmonis ini terutama disebabkan oleh perbedaan pandangan para pendiri republik ini, yang sebagian besar muslim, mengenai Indonesia yang dicita-citakan. Salah satu butir terpenting dalam perbedaan di atas adalah apakah negara Indonesia bercorak Islami atau nasionalis.

Selama ini pemikiran Ahmad Hassan yang tertuang dalam Persatuan Islam seperti gerakan-gerakan di Indonesia, memberikan perhatian yang sangat besar terhadap bentuk pemerintahan Indonesia di masa depan dan apakah ia pada akhirnya akan menerima karakter Islam. Ahmad Hassan dan para anggota Persis lainnya menggabungkan diri mereka ke dalam

${ }^{30}$ Deliar Noer, Gerakan Modern Islam Indonesia 1900- 1942, (Jakarta: LP3ES, 1996), I.

${ }^{31}$ Bahtiar Effendi, Teologi Baru Politik Islam, (Yogyakarta: Galang Press, 200 I), vii. 
negara Indonesia yang muncul selama era Revolusi dan menganggap keberadaannya sebagai realitas sejarah yang penting. Bagaimanapun, keberadaan bangsa Indonesia merupakan personifikasi dari kemerdekaan yang telah diperjuangkan begitu lama melawan Belanda dan Jepang. ${ }^{32}$

Ahmad Hassan mewajibkan kepada seluruh umat Islam terkait masalah yang dihadapi bangsa Indonesia. Maka seharusnya kaum muslimin memahami secara lebih baik ajaran-ajaran agama mereka. Ahmad Hassan menekankan bahwa hukum syari'at lebih maju daripada hukum adat maupun hukum sekuler, dan penolakannya untuk mengakomodasikan kedua sistem itu, kecuali dalam masalah-masalah yang tidak mendasar, tidak mendamaikan tiga kecenderungan luas yang berkembang dalam kehidupan sosial dan politik bangsa Indonesia itu. Penekanan Ahmad Hassan seperti itu juga dimaksudkan untuk menyajikan pemahaman yang khas bagi umat Islam mengenai masalah-masalah yang dihadapi para pemeluk sistem ajaran yang lain. ${ }^{33}$

Sumbangan khusus Ahmad Hassan yang termuat dalam Persatuan Islam terhadap perkembangan Islam di Indonesia adalah peranan yang dimainkannya bagi kalangan awam dalam menentukan prilaku keagamaan mereka sendiri. Baik kalangan tradisionalis maupun modernis telah memberikan penekanan yang besar terhadap ulama', yang secara umum agak meninggalkan kalangan awam dan hanya memperhatikan ajaran dan praktek keagamaan bagi dirinya sendiri yang sejalan dengan pandangan-pandangan ulama yang pernah didengarkannya secara langsung. Walaupun melakukan penelitian masalah keagamaan, tetapi Ahmad Hassan tetap memberikan sedikit kesempatan kepada kalangan awam untuk ikut serta dengan sedikit pemahaman mereka. Dengan cara ini, kalangan awan akan memilih diantara keputusan-keputusan dari berbagai ulama

\footnotetext{
32 Howard M Federspiel, Labirin Idiologi Muslim, 340.

${ }^{33}$ Howard M. Federspiel, Persatuan Islam, 243.
} 
mengenai masalah-masalah yang mempengaruhi pemahaman dan praktek keagamaan mereka. ${ }^{34}$

Allan Samson sebagaimana dikutip oleh Zakki Fuad menyatakan pandanganya tentang Religio Political Behavior menyatakan bahwa, Ahmad Hassan adalah seorang tokoh yang "fundamentalis". Ia berkeyakinan hanya Islam yang memberikan dasar dan moral bagi negara, dan bahwa undang-undang, dan peraturan-peraturannya mewujudkan perintah al-Qur'an haruslah dilaksanakan. ${ }^{35}$ Dalam memberikan dasar-dasar pemerintahan Islam Ahmad Hassan mengutip surah an-Nisa': 59 yang artinya: "Taatlah kepada Allah dan taatlah kepada Rasul dan kepada ketua-ketua diantara kamu.".

Ahmad Hassan menyatakan bahwa ayat diatas mewajibkan kita taat kepada Allah, Rasul dan ketua-ketua kita. Allah dan Rasulnya maksudnya ialah menjalankan perintah dan menjauhi larangan-larangannya dan menghukum menurut apa yang ada dalam al-Qur'an dan Hadits. Sedangkan ketua-ketua maksudnya adalah tidak dalam urusan ibadah, tapi semata-mata masalah keduniaan, karena ibadah itu adalah hak Allah dan Rasul-Nya.

Dari berbagai sudut pandang, ajaran, serta aktifitas Ahmad Hassan dengan kelompok lain menunjukan bahwa, selama era ini, Ahmad Hassan merupakan begian dari dunia Sunni. Ahmad Hassan memiliki kesamaan dengan gerakan-gerakan pembaharuan modernis di dunia Islam lainnya. Terdapat kesamaan yang mencolok antara penjelasan Ahmad Hassan dan penjelasan Afgani-Abduh-Ridha tentang modernisme Islam. Dan sesungguhnya, seluruh gerakan modernis di Indonesia merupakan perkembangan lanjutan dari mazhab pemikiran tersebut. Lebih lanjut, Ahmad Hassan muncul pada saat belum di gunakannya istilah "fundamentalis" untuk menyebut kelompok-kelompok muslim yang memiliki pemikiran kaku tentang ajaran-ajaran agama dan mengharuskan seluruh muslim untuk menerima

${ }^{34}$ Ibid., 245.

${ }^{35}$ AH Zakki Fuad, Negara Islam atau Negara Nasional, Pemikiran Fundamental Vs Liberal, I 49. 
ajaran-ajaran Islam versi mereka. ${ }^{36}$ Dalam pandangan fundamentalis, seiring dengan kecenderungan penafsirannya terhadap doktrin yang bercorak rigid (kaku) dan literalis, fundamentalisme memandang bahwa corak pengaturan doktrin bersifat total dan serba mencukup, tidak ada masalah-masalah yang berhubungan dengan kehidupan manusia di dunia ini yang luput dengan jangkauan doktrin yang serba mencukup itu. ${ }^{37} \mathrm{Hal}$ itu sejalan dengan pemikiran Ahmad Hassan yang menginginkan Islam memasuki seluruh aspek kehidupan.

Dalam pandangan Howard M Federspiel, Ahmad Hassan di golongkan dalam pemikir yang fundamental, yang ingin mengubah masyarakat sampai ke akar-akarnya, dan ingin menghancurkan penyakit umat Islam dengan cara yang radikal dan revolusioner, secara jelas, tanpa samar-samar, tanpa sungkansungkan, dan dengan penuh kepastian. ${ }^{38}$

Pandangan Ahmad Hassan yang tergambar dalam pandangan Persatuan Islam, tentang negara Islam adalah mirip dengan pandangan Muhammadiyyah, karena Ahmad Hassan dan pemimpin-pemimpin Persatuan Islam meyakini bahwa masyarakat terlebih dahulu harus di bentuk sebelum sebuah negara Islam benar-benar dapat kuat dan efektif. Isa Anshary menyatakan bahwa tujuan kaum muslimin, baik politik agama, sosial atau ekonomi akan berhasil apabila pertama-tama diciptakan suatu masyarakat yang dibangun secara spiritual oleh anggota-anggotanya. Dalam hal ini, Ahmad Hassan melihat aktifitas politik sangat berguna dalam promosi religius diseluruh lapisan masyarakat disamping berguna untuk memerangi apa yang ia anggap sebagai kecenderungan-kecenderungan sekuler yang membingungkan yang di promosikan oleh partai-partai politik non-muslim.

\footnotetext{
${ }^{36}$ Howard M Federspiel, Labirin Idiologi Muslim, 240.

${ }^{37}$ Yusril Ihza M, Modernisme dan Fundamentalisme, 31.

${ }^{38}$ Howard M. Federspiel, Persatuan Islam, 202.
} 
Pemikiran Ahmad Hassan yang tertuang dalam Persatuan Islam meyakini bahwa perintah dan larangan yang ditegaskan dalam al-Qur'an dan Sunnah berupa larangan minum-minuman keras, berjudi, melakukan tindakan moral, harus segera dilaksanakan dalam negara. Terkait masalah hukum-hukum yang lain dalam sebuah negara, Ahmad Hassan beranggapan bahwa hal-hal yang berkaitan dengan hukum yang lain akan ditentukan oleh para legeslasi-legeslasi dan pengadilan-pengadilan yang merujuk pada ajaran agama. Dengan mengambil rujukan pada alQur'an dan Sunnah. ${ }^{39}$

Ahmad Hassan menghadirkan ide keagamaan yang mengambarkan peribadatan dan kewajiban syari'at lainnya sebagai faktor penting dalam kehidupan. Ahmad Hassan juga menekankan agar kaum muslimin menghilangkan semua kepercayaan dan praktek yang dipandang bertentangan dengan Islam. Usaha untuk menjadikan Islam untuk menjadikan Islam sebagai faktor yang penting bagi kehidupan bangsa Indonesia bukan merupakan usaha yang baru dalam sejarah Islam, sebab hal itu sudah menjadi komitmen Islam. Misi Ahmad Hassan menyatakan kembali kepada cita-cita sejarah Islam dalam sebuah bangsa yang belum lama memeluk Islam. ${ }^{40}$

Dalam bangsa seperti itu terdapat lembaga-lembaga keagamaan asli yang sudah tidak mengembangkan pandangan yang sesuai dengan cita-cita Islam itu. Pesan Ahmad Hassan itu bertujuan untuk mengembangkan, memperdalam dan memperluas keimanan serta praktek keagamaan di Indonesia sehingga dengan demikian menjadikan Islam sebagai faktor yang dominan bagi bangsa Indonesia dan kehidupan nasional Indonesia. ${ }^{41}$

Ahmad Hassan menulis dua pamflet yang mendukung pemerintahan republik pada awal tahun 1946, yang

\footnotetext{
${ }^{39}$ lbid., 214.

40 lbid., 24l.

${ }^{41}$ Ibid., 242.
} 
mengidentifikasi aktivisme politik muslim dengan negara Indonesia baru. Dalam tulisannya yang berjudul Kedaulatan, yang tampaknya ditujukan untuk menjawab kritik dan ketidaksabaran beberapa faksi muslim terhadap pemerintahan Soekarno. Ahmad Hassan meyakinkan kepada kaum muslimin tentang pentingnya persatuan, maka dari itu, umat muslim harus menegakkan sebuah pemerintahan Indonesia yang berdasarkan pada hukum agama Islam. Ahmad Hassan berpendirian, jika Indonesia menjadi negara sekuler akan banyak kekurangan, tetapi kekurangan yang disebabkan sekularisme itu harus diperangi secara damai, dengan khotbah-khotbah dan nasehat-nasehat yang bijak. ${ }^{42}$

\section{Pemikiran Ahmad Hassan dalam Tipologi Pemikiran Islam}

Banyak konstruk pemikiran yang melahirkan berbagai pandangan tentang bagaimana kita, sebagai kaum muslimin menyikapi politik. Tentang bentuk kenegaraan yang seperti apa yang harus dipakai oleh suatu negara. Dari beberapa pemikiran para tokoh itu semua yang ahirnya mengarah pada karakter dan tipologi politik Islam itu sendiri. Namun secara umum para pemikir membaginya dalam tripologi. Dalam pandangan A. Djazuli, beliau membagi kerangka berfikir dunia Islam dewasa ini menjadi tiga tipe, pertama, liberal (sekuler) yaitu negara menolak hukum Islam secara penuh, kedua, fundamental (intergralistik) yaitu negara melaksanakan hukum Islam secara penuh, ketiga, moderat (simbiotik) yaitu negara yang tidak menjadikan sebagai suatu kekuatan struktural (dalam sektor politik), tetapi menempatkannya sebagai kekuatan kultural, atau mencari kompromi. ${ }^{43}$ Sedangkan menurut Din Syamsuddin, paradigma

\footnotetext{
${ }^{42}$ Howard M. Federspiel, Labirin Idiologi Muslim, 303.

43 A. Djazuli, Fiqh Siyasah: Implementasi Kemaslahatan Umat dalam Rambu-Rambu Syariah, (Bogor: Prenada Media, 2003), Cet II, 39.
} 
pemikiran politik Islam modern dibagi atas "tradisionalis", "modernis", dan "fundamentalis". 44

\section{Tipologi Liberal}

Paradigma liberal, sesuai dengan maknanya yang sederhana, adalah bebas, merdeka dan tidak terikat. apabila diletakkan dalam konteks pemikiran, maka seorang yang memiliki tipikal berfikir liberal adalah mereka yang bebas untuk berfikir dan mengeluarkan pendapat serta merdeka tanpa harus terikat pada segala bentuk pengetahuan dan otoritas manapun. Model demikian biasanya menjunjung tinggi martabat pribadi manusia dan kemerdekaanya. Manusia sebagaimana yang pernah menjadi diktum awal renaissance adalah subyek otonom. Subyek yang memiliki kesadaran untuk berfikir, berbuat dan bertindak. ${ }^{45}$

Pola liberal ini menekankan pemisahan antara agama dan negara, yang menyatakan bahwa dalam Islam tidak ditemukan aturan-aturan yang berkaitan dengan masalah politik atau kenegaraan. Islam hanyalah mengatur hubungan antara menusia dan Tuhan. Para penganut tokoh ini beranggapan bahwa agama itu bersifat universal sedangkan politik itu portikular (individu), maka dari itu antara agama dan politik tidak bisa bersatu.

\section{Tipologi Fundamental}

Secara harfiah istilah fundamental berarti mendasar, yang digunakan untuk menunjuk sikap politik suatu kelompok yang ekstrim, fanatik dan keras kepala. Golongan mengungkapkan bahwa Islam mencakup semua aturan kehidupan, termasuk urusan politik atau kenegaraan. Argumen yang diberikan oleh

\footnotetext{
${ }^{44}$ M. Din Syamsuddin, Islam dan Politik, Era Orde Baru, (Jakarta: PT Logos Wacana IImu, 200 I), 116.

${ }^{45}$ Listiyono Santoso, Teologi Politik Gus Dur, 89.
} 
kelompok ini, bahwa Nabi telah selesai dan telah memberikan garis panduan yang jelas seperti ketika Nabi berada di Madinah. ${ }^{46}$

Di pusat Islam (Makkah-Madinah), semangat pembangunan sosio-moral mencapai puncaknya pada abad ke-18 dengan gerakan fundamentalis yang dikembangkan oleh Abd al-Wahab. Para pengikutnya menyebut dirinya sebagai "Muwahhidun" yang berarti pengikut tauhid, tetapi mereka umumnya lebih dikenal dengan sebutan Wahabi., gerakan Wahabi mengambarkan prototipe semangat fundamentalisme dalam pengalaman Islam $\operatorname{modern}^{47}$.

Disamping garis perkembangan fundamentalis tersebut, tahun 1970-an merupakan suatu periode dimana bentuk fundamentalis juga memiliki bentuk yang radikal. Ungkapan kesetiaan terhadap al-Qur'an dan Sunnah serta penolakan dengan lembaga-lembaga yang ada dalam tradisi abad pertengahan, Fundamentalisme radikal terikat dalam suatu reorientasi tentang tradisi Islam. Radikalisme ini merupakan sintesis dari radikalisme yang telah ditransformasikan pada tahun 1960-an dan semangat fundamentalis Islam. Fundamentalis radikal menekankan partisipasi masa, kontrol partisipatori, identitas unit yang kecil dan menghilangkan perbedaan-perbedaan sosio-politik lama ${ }^{48}$.

\section{Tipologi Moderat}

Pemikiran ini mengutarakan bahwa dalam Islam tidak ada aturan yang pasti tentang masalah politik atau tata negara, namun ada prinsip atau asas yang harus ditegakkan. Memang Rasulullah S.A.W bukan diutus sebagai pemimpin politik, tetapi sebagai Rasul. Perlu diketahui, konsep kerasulan beliau tidak sebatas menyampaikan pesan Allah (dakwah). Yang paling berat adalah

\footnotetext{
46 Moh. Nurhakim, Islam Responsif: Agama di Tengah Pergulatan Idiologi Politik dan Budaya Global, (Malang: Universitas Muhammadiyah Malang, 2005), I00- 102.

47 John Obert Voll, Politik Islam: Kelangsungan dan Perubahan di Dunia Modern, (Jogjakarta: Titian llahi Press, 1997), 90.

48 Ibid., 356.
} 
menjadi contoh dan suri-tauladan dalam melaksanakan Islam sebagai cara hidup (way of life). Dalam masa yang singkat, beliau telah berhasil membuat perubahan dan reformasi kesesuaian dimana budaya, pemikiran dan sosio-politik bangsa Arab maju dan gemilang. Semua perubahan ini berlaku karena beliau telah membuat perancangan dan program yang jitu dan bijaksana. Ini dapat dilihat bagaimana beliau berhijrah, membina persaudaraan, membentuk tatanan sosial, membangun ekonomi, politik, dan sosial umat Islam di Madinah.

Dalam konteks paradigma simbiotik ini, Ibnu Taimiyyah mengatakan bahwa adanya kekuasaan yang mengatur kehidupan manusia merupakan kewajiban agama yang paling besar, karena tanpa kekuasaan negara, maka agama tidak akan bisa berdiri tegak. Pendapat Ibnu Taimiyah tersebut melegitimasi bahwa antara politik dan agama merupakan dua entitas yang berbeda, tetapi saling membutuhkan. Oleh karenanya, konstitusi yang berlaku dalam paradigma ini tidak saja berasal dari adanya social contract, tetapi bisa saja diwarnai oleh hukum agama (syari'ah). Singkatnya, syari'ah memiliki peran sentral sebagai sumber legitimasi terhadap realitas politik. ${ }^{49}$

Fazlurrahman adalah salah satu penggagas yang dinilai sementara kalangan sebagai pemikir orisinal tentang Islam. Terutama ide-ide neo-modernisme yang merupakan gagasan brilian yang hadir dalam wacana baru menggali sumber-sumber nilai Islam langsung pada pokoknya yaitu al-Qur'an. Neomodernismenya memang selain menyuarakan kemodernan pemahaman Islam juga ditambah dengan kemampuan mengunakan metodologi sistematik tentang al-Qur'an. Begitu juga dalam pemikiran modernisme, lebih banyak mengadopsi gagasan barat dalam perspektif pemikiran barat. Sehingga ada kesan orisinalitas pemikiran Islam telah terbaratkan dalam wacana modernisme. Jadi pemikiran neo-modernisme mengambil bentuk

${ }^{49}$ M. Din Syamsudin "Usaha Pencarian Konsep Negara dalam Sejarah Pemikiran Politik Islam", Dalam Abu Zahra, Politik Demi Tuhan, Nasionalisme Religius di Indonesia, 45. 
paling mutahir baik dalam terma-terma keIslaman maupun metodologisnya ${ }^{50}$.

Al-Qur'an dan Sunnah dinilai memuat pesan-pesan universal. Namun pesan itu tidak akan mudah ditangkap, apabila orang kehilanggan cara memahami dalam perspektif yang bersifat histories dengan mempunyai dua dimensi global, pertama dimensi Islam sejarah dan kedua dimensi Islam cita-cita. Jadi Islam harus ditangkap secara utuh dan mempertimbangkannya secara kritis latarbelakang sosio-kultural turunnya ayat. Apabila tidak mampu menagkapnya, maka akan kehilangan ruhnya yang berarti dalam porsoalan nilai praktis kemanusiaan dengan kehidupan kolektif. Disinilah dinamakannya esensial moral kandungan al-Qur'an mutlak diselami terlebih dahulu sebelum dengan tegas menetapkan kekuatan hukum atas suatu persoalan. ${ }^{51}$

\section{Sosok dan Pemikiran Ahmad Hassan dalam Pandangan Beberapa Tokoh}

Berbeda pendapat adalah merupakan hal yang biasa terjadi antara manusia satu dengan manusia lainnya. Perbedaan itu bukan saja terjadi diantara pemeluk agama, tetapi juga antara satu pemeluk agama, misalnya saja antara pemeluk Islam itu sendiri. Tetapi sepanjang perbedaan itu tidak menyangkut prinsip-prinsip akidah, maka ia diharapkan akan mambawa rahmad dan hikmah yang besar, bila didasarkan dengan pemikiran dan pertimbangan yang sehat.

Demikian juga apa yang terjadi pada sosok Ahmad Hassan. Dengan berbagai pendapatnya serta buah pemikirannya, beliau memperoleh tanggapan-tanggapan dari berbagai pihak, termasuk para ulama' dan pemimpin Islam dan juga negarawan Indonesia sendiri terkait masalah politik keneganraan Ahmad Hassan.

50 Abdul Sani, Lintasan Sejarah Perkembangan Modern dalam Islam, (Jakarta: PT Grafindo Persada, 1998), 258.

${ }^{51}$ Ibid., 259. 
Ahmad Hassan sendiri tahu bahwa pendirianya yang terlalu keras dalam agama itu akan menimbulkan banyak orang benci dan memusuhinya, bahkan dari teman-temanya sendiri. Tapi beliau tidak memperdulikan itu. Disayangi atau dibenci, buat Ahmad Hassan adalah urusan orang lain. Tapi bagaimanapun orang membenci dan memusuhinya, ia tidak pernah memberi kesempatan (jalan) buat orang lain untuk memusuhi pribadinya. ${ }^{52}$

Salah seorang yang memberikan tanggapan terhadap pikiran Ahmad Hassan adalah Hamka. Hamka menyatakan bahwa, orang ketiga yang menjadi penyiar Abduh di Jawa adalah Syaikh Ahmad Hassan. Dan keistimewaan beliau adalah kekuatan hujjahnya dan teguhnya mempertahankan pendirian yang beliau yakini kebenarannya. Ahmad Hassan adalah orang yang kuat hatinya, kuat hujjahnya dan pahit kritiknya, kalau perlu terhadap kawannya sendiri beliau berkata dengan jujur, meskipun hal itu menyakiti hatinya.

Sedangkan H. Tamar Djaja memberikan komentar bahwa, kalau dikatakan bahwa Ahmad Hassan adalah ulama' yang paling alim diseluruh Indonesia, mungkin dianggap terlalu dibesarbesarkan. Akan tetapi menurut ulama'-ulama' terbesar di Jawa yang ditanya beliau, menyatakan bahwa Ustadz Ahmad Hassan alim besar. ${ }^{53}$

Ahmad Sorkati, ulama' asal Sudan yang juga pendiri Jamiyyah Al-Irsyad itu, memberikan tanggapan tentang Ahmad Hassan. Bahwa Ahmad Hassan adalah orang yang terpelajar, mempunyai tingkatan tauhid yang tinggi, dan seorang pembela agama Allah yang selalu berjuang menghindarkan umat Islam dari kesesatan. ${ }^{54}$

Sebagai manusia, Ahmad Hassan mempunyai batasan usia. Beliau telah tiada. Tapi semangat pemurnian Islam yang dikumandangkannya dan ilmu yang diwariskannya, tidak akan

\footnotetext{
${ }^{52}$ Abdul Rahman Abdullah, Gerakan Islam di Perlis, Sejarah dan Pemikiran, 133.

53 Syafiq A. Mughni, Hassan Bandung, Pemikir Islam Radikal, 42.

${ }^{54}$ Harry Muhammad, dkk, Tokoh-Tokoh Islam yang Berpengaruh Abad-20, 20
} 
pernah pudar. Semoga kita bisa mengambil hikmah dan pelajaran dari ini semua. ${ }^{55}$

\section{Penutup}

Dalam memandang politik Islam di Indonesia, prinsip dasar keyakinan Ahmad Hassan adalah mewujudkan suatu negara Islam yang sesuai dengan yang di kehendaki Tuhan. Maka, hal itu bisa tercapai dengan cara: pertama, kaum muslimin harus melaksanakan seluruh ajaran Islam dalam setiap segi kehidupan. Kedua, menempatkan umat Islam pada ajaran Islam yang murni berdasarkan al-Qur'an dan Sunnah, baik dalam akidah (kepercayaan dan keyakinan) maupun syari'at (hukum agama). Sistem kehidupan atau bentuk negara dalam pandangan Ahmad Hassan yaitu: pertama, adanya jama'ah (kehidupan yang bersatu). Kedua, mempunyai pemimpin (imama), dan ketiga, mempunyai kekuasaan (imarah). Ketiga unsur tersebut di atas menurut beliau telah di contohkan oleh Rasulullah.

Dalam penerapan konsep politik. Ahmad Hassan berkeyakinan bahwa pemerintahan Islam adalah pilihan lain dari faham kebangsaan yang dianggapnya tidak memberikan tempat bagi agama. Islam dipandang sebagai sesuatu yang tertinggi dan terluas menerjang batas-batas kebangsaan dan ketanahairan. Dalam teori pemerintahan cara Islam, Menurut Ahmad Hassan sebagai upaya untuk mendamaikan teori politik Islam dengan teori-teori pemerintahan demokrasi modern. Ahmad Hassan beranggapan bahwa demokrasi telah diakui di awal Islam dalam pemilihan khilafah pertama Abu Bakar dan dalam sebuah pernyataan yang dibuat oleh khalifah Umar. Dan sebenarnya, seluruh dunia telah belajar demokrasi dari Islam. Pemerintahan Islam didasarkan pada al-Qur'an dan musyawarah, karena Islam memiliki ketentuan-ketentuan khusus yang tidak dapat dilanggar, maka ia mengeliminir banyak perangkap demokrasi yang semata-

${ }^{55}$ Ibid., 19.

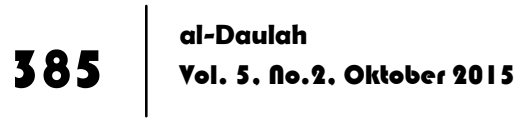


mata didasarkan pada kehendak rakyat, yang mungkin saja memilih banyak dosa. Ahmad Hassan menyimpulkan bahwa bentuk-bentuk demokrasi Islam tidak berbeda dari bentuk-bentuk demokrasi lain dan pejabat-pejabat seperti perdana menteri dan lembaga-lembaga seperti kabinet dan parlemen akan dibutuhkan, bahkan walau dalam Islam.

Dalam peta politik Islam, Ahmad Hassan bisa dikatagorikan sebagai pemikir Islam fundamental karena Ahmad Hassan berkeyakinan bahwa hanya Islam yang memberikan dasar dan moral bagi negara, agama telah memberikan ajaran yang lengkap bagi kehidupan manusia. Dan bahwa undang-undang serta peraturan-peraturannya yang sesuai dengan al-Qur'an haruslah dilaksanakan. Ahmad Hassan ingin mengubah masyarakat sampai ke akar-akarnya, dan ingin menghancurkan penyakit umat Islam dengan cara yang radikal dan revolusioner secara jelas tanpa samar-samar dan penuh kepastian.

\section{Daftar Pustaka}

Aziz, Abdul. Politik Islam Politik. Yogyakarta: Tiara Wacana, 2006.

Djazuli, H.A. Fikih Siyasah: Implementasi Kemaslahatan Umat dalam Rambu-rambu Syari'ah. Bogor: Prenada Media, Cet II, 2003.

Effendi, Bahtiar. Teologi Baru Politik Islam. Yogyakarta: Galang Press, 2001.

Federspiel, M. Howard. Persatuan Islam. Yogyakarta: Gajah Mada Universiti Press, 1996.

------. Labirin Idiologi Muslim. Jakarta: PT Serambi Ilmu Semesta, 2004.

Fuad, AH. Zakki. Negara Islam atau Negara Nasional. Kediri: Jenggala Pustaka Utama, 2007.

Hassan, A. Islam dan Kebangsaan. Bangil: Persatuan, Cet III, 1972.

Iqbal, Muhammad. Figh Siyasah: Kontekstualisasi Doktrin Politik Islam. Jakarta: Gaya Media Pranata, 2001. 
Ma'arif, Ahmad Syafi'i. Islam dan Masalah Kenegaraan, Studi Tentang Pencarian dalam Konstituante. Jakarta: LP3ES, Cet III, 1996.

Mughni, A. Syafiq. Hassan Bandung: Pemikir Islam Radikal. Surabaya: PT Bina Ilmu, 1994.

Noer, Deliar. Gerakan Modern Islam Indonesia 1900-1942. Jakarta: LP3ES, 1996.

Nurhakim, Moh. Islam Responsif: Agama di Tengah Pergulatan Idiologi Politik dan Budaya Global. Malang: Universitas Muhammadiyah Malang, 2005.

Rahman, Deddy. Ulama' Besar. dalam www.adiynawawi.com, diakses Maret 2009.

Sani, Abdul. Lintasan Sejarah Pemikiran: Perkembangan Modern dalam Islam. Jakarta: PT Grafindo Persada, 1998.

Santoso, Listoyono. Teologi Politik Gus Dur. Jogjakarta: ArRuzzjogjakarta, 2004.

Shoffan, Moh. Jalan Ketiga Pemikiarn Islam: Mencari Solusi Perdebatan Tradisionalisme dan Liberalisme. Jogjakarta: Ircisod, 2006.

Syafi'ie, Inu Kencana. Ilmu Politik. Jakarta: PT Rieneka Cipta, 2000.

Syamsuddin, M. Din. Islam dan Politik, Era Orde Baru. Jakarta: PT Logos Wacana Ilmu, 2001.

Voll, John Obert. Politik Islam: Kelangsungan dan Perubahan di Dunia Modern. Jogjakarta: Titian Ilahi Press, 1997. 